\title{
Maintaining Health and Well-Being by Putting Faith into Action During the COVID-19 Pandemic
}

\author{
Harold G. Koenig ${ }^{1,2,3,4}$ \\ Published online: 14 May 2020 \\ ๑) Springer Science+Business Media, LLC, part of Springer Nature 2020
}

\begin{abstract}
Anxiety and fear adversely affect the physiological systems that protect individuals from infection. This article comments on the role that religious faith and practice can play in helping individuals remain free from infection by the coronavirus and in helping to moderate the effects of infection if that should occur. The author provides six recommendations to help individuals maintain spiritual, mental, and physical resilience during these anxious times of the COVID-19 pandemic.
\end{abstract}

Keywords Religion · Religiosity · Coronavirus · COVID-19 · Protection · Immune function

Many throughout the world are now experiencing fear and anxiety, especially those who are older, have underlying medical conditions, and even young people who are healthy and vigorous. The fear is over the "novel coronavirus," as it is officially called. The scientific name is severe acute respiratory syndrome coronavirus 2 (SARS-CoV-2). Infection with this nasty villain produces the deadly respiratory disease called COVID-19, which presents with fever, a deep dry cough, and shortness of breath (and sometimes loss of taste and smell, or intestinal problems). COVID-19 is a condition that can progress rapidly and, in some cases, end up in death.

\footnotetext{
This has been expanded to address a general audience from an original paper written for clinicians caring for older adults, which is to be published in the American Journal of Geriatric Psychiatry: Koenig, H.G. (2020). Ways of protecting religious older adults from the consequences of COVID-19. American Journal of Geriatric Psychiatry, forthcoming.

Harold G. Koenig

Harold.Koenig@duke.edu

1 Department of Psychiatry and Behavioral Sciences, and Department of Medicine, Duke University Medical Center, Box 3400, Durham, NC 27710, USA

2 Department of Medicine, King Abdulaziz University, Jeddah, Saudi Arabia

3 Ningxia Medical University, Yinchuan, People's Republic of China

4 Shiraz University of Medical Sciences, Shiraz, Iran
} 
Few, however, understand that the very emotions we are all now experiencing actually increase our susceptibility to the dreaded virus. This is because of the adverse effects on immune functioning that fear, anxiety, and psychological distress cause (Glaser and Kiecolt-Glaser 2005; Coughlin 2012). Positive emotions, though, have the exact opposite effect on the immune system as do fear and anxiety. Among Christians, these positive emotions are known as the "fruit of the spirit" (love, joy, peace, forbearance, kindness, goodness, faithfulness, gentleness and self-control; Galatians 5:22-23). Indeed, the first of these is known to cast out fear (1 John 4:18).

Similarly, the Islamic faith gives believers the hope that perfect happiness, peace, tranquility, security and freedom from fear will be present in Paradise, and those who do good deeds and have faith are guaranteed to have a good life here and an everlasting life in Paradise (Qur'an 2:82; 16:97). For Jews, Tehillim (Psalm) 32:11 instructs believers to "Be glad in HaShem, and rejoice, ye righteous; and shout for joy, all ye that are upright in heart," while Tehillim 91:2-3 promises protection for those who take refuge in G-d during epidemics: "I will say of HaShem, who is my refuge and my fortress, my G-d, in whom I trust, that He will deliver thee from the snare of the fowler, and from the noisome pestilence [widespread infection]."

In Buddhism, the central characteristic of a Buddhist saint (bodhisattva) is acting compassionate toward others. The promised reward is peace and tranquility, as the doer of good deeds is assured joy and bliss both now and also in the hereafter (Dhammapada 16, 28). In fact, randomized controlled trials show that practice of the 7th step on the Eightfold Path, mindfulness, decreases stress levels (Hazlett-Stevens et al. 2019). Mindfulness meditation may also be adapted for Christian elders to reduce stress and anxiety (Ford and Garzon 2017), and similar effects may be achieved by Centering Prayer, which is very much like mindfulness (Blanton 2011). In Hinduism, the Bhagavad Gita emphasizes that fixing one's mind on the Supreme God provides happiness and peace here and now $(5: 21 ; 18: 65)$. Research has shown that Hindu-based meditation reduces anxiety and increases positive emotions (Pandya 2019), as does Hindubased yoga practices (Bonura 2011).

The benefits to the immune system of positive emotions, including those generated by sacred scriptures and activities like those above, are backed by a large and growing volume of objective scientific research (Pressman and Black 2012; Wilson et al. 2017; Brown et al. 2020).

For many, religious faith is an important resource for health and well-being, one whose effects should not be underestimated (Koenig et al. 2012, 2020). Here are six suggestions for those who want to remain healthy and resilient-mentally, physically, and spiritually-during this anxious time of the coronavirus pandemic (and help the faithful stay busy and avoid social isolation while sheltering in place at home). Many of these suggestions are widely known, but some may also be new ones that readers are not aware of. 


\section{Deepen Your Religious Faith}

As many have said, this is a wonderful time to develop a stronger relationship with God by concentrating on personal religious activities. These may involve praying to God or meditating (Christian centering prayer, Buddhist mindfulness meditation, or Hindu transcendental meditation); reading sacred scriptures such as the Bible, Qur'an, Bhagavad Gita, or Dhammapada; spending time thinking about and applying these sacred scriptures to one's life; memorizing scriptures or reciting them aloud; listening to or watching inspirational programs on radio, podcast, or $\mathrm{TV}$; or otherwise engaging in private religious activities that are encouraged by one's faith tradition. Although attending religious services together is not possible at the present time due to COVID-19 restrictions, people of faith can often congregate "virtually" by participating in services that are now being live streamed. When life was "normal," one might have been so busy that there was no time for spiritual matters, with hobbies, jobs, housework, recreational activities, social and family activities filling up every moment of the day. Now that normal activities have virtually come to a halt, there is lots of time for activities that will help build spiritual health.

A large and growing volume of research now documents the benefits of religious faith on immune functioning and vulnerability to infection, viral infection in particular (see below). In practical application of these research findings, one physician-when treating a religious patient with panic attacks due to fear of the coronavirus-prescribed clonazepam three times a day. With that prescription, he instructed the patient to read Psalm 91 out loud immediately after taking each dose. As noted above, Psalm 91 mentions protection from "pestilence" no fewer than three times for those who take refuge in God.

\section{Love Thy Neighbor as Thyself}

This is what Jesus said in three of the four Gospels (Matthew 22:39; Mark 12:31, Luke 10:27). He was simply quoting what Moses commanded in Leviticus 19:17. A similar point has been made by the Prophet Mohammad, the Buddha, many Hindu writers, and other greater religious figures, so there is very little wiggle room here, regardless of a person's specific religious tradition. Coronavirus pandemic or not, the faithful are instructed to love and care for the neighbor. Who is my neighbor? As Jesus illustrated in the parable of the Good Samaritan (Luke 10:25-37), the answer is anyone in need. There are a lot of people out there in need right now.

One reason why early Christianity spread so rapidly throughout Europe and Middle East in the first several centuries was because of infectious plagues that were decimating the population in Europe and countries around the Mediterranean (Numbers and Amundsen 1986, pp 48-49). Christians were those who stepped up to care for Christians and non-Christians alike, often risking their own 
lives to do so. This made such an impression on non-Christians that they began to convert to the Christian faith. They saw something different about these Christians and wanted what they had. Many priests today in Italy have likewise lost their lives caring for those infected with the coronavirus in that country. There is now the same opportunity for those of all professions and religious faiths to spread God's love and hope to family members, neighbors, friends, and anyone else in need, while minimally increasing the risk of their own safety.

\section{Use Technology}

"Social distancing" means physically separating from one another by six feet. The importance of following this directive is without saying, but this should not mean becoming socially distant from one another. People cannot give each other physical hugs or handshakes now to prevent the coronavirus spread. However, there are ways of providing hugs and handshakes through the technology that is now available. For example, there is a Marco Polo phone app that allows recording of a video message. The recipient can watch it whenever desired (and also video record a message and send it back to the person). This app informs the individual when a message arrives by a red dot on the app and a beep. This may be especially helpful for less tech-savvy relatives who are isolated at home. If a family member does not have a cell phone, consider purchasing one and teaching the person how to use it (perhaps doing this by landline). Is it not amazing that at this time in history there is technology capable of connecting virtually everyone during this crucial period? From a faith perspective, God has allowed the coronavirus pandemic for some reason at this particular time in history, and it coincides with the present booming age of technology that connects people both near and far at virtually no cost or risk to health.

\section{Love and Care for Neighbor in Practical Ways}

What do the scriptures that command believers to "love your neighbor," perform acts of "compassion," or do "good deeds" mean in a practical sense? It means putting faith into action, such as caring for the emotional, spiritual, and physical needs that others may have. Here are two concrete actions that anyone can do, one from the safety of their home and the other from the safety of their car.

First, spend time at home thinking about family, friends, members of your congregation, colleagues at work, or others who might be at risk for social isolation, especially those who are living alone or are dealing with physical or emotional health problems. There are hundreds of thousands of older adults in nursing homes, and given the new ban on visitors, they too are at risk. Many nursing homes are even making residents stay in their rooms, which means no congregating with other residents for meals, socializing, or recreational activities. Once an individual (or individuals) is identified that meet this criterion, contact them and ask if they would like to have a spiritual partner during these unsettling times (many will likely say yes, often enthusiastically). Partnering means contacting them at times that are agreed 
on, perhaps several times per day. This time would be spent praying for and with one another, listening, and sharing God's love and hope. This will not only give a sense of meaning and purpose to those dreary endless hours spent at home, but also dispel boredom that can easily creep in when unable to get out of the house. The technology is now available to do this from the safety of home. Not only will this spread a message of love and hope, but will enhance the initiator's own health and wellbeing by doing something good that the scriptures of all faith traditions say will be rewarded many-fold both in this life and the next.

The second way to put faith into action involves a bit more risk, but this too can be done sensibly. Many individuals now have physical needs-especially those in difficult economic circumstances. Loving these individuals might involve picking up food or medical supplies for them at a grocery store or pharmacy, driving to the person's home and leaving the supplies in a safe place, where the person can easily access them. No need to come into any physical contact with these individuals. Simply let them know immediately by calling them on the phone that the supplies have been delivered.

\section{Don't Be Reckless}

These are dangerous times that we live in and a cavalier attitude is not an attitude of faith. Caring for self is part of the Judeo-Christian great commandment that instructs to love others as you love yourself. No faith tradition condones recklessness. People should not expose themselves (or others) to the coronavirus. Anyone with a cold, especially if they have a fever and cough, should not have close physical contact with others (especially with older adults, anyone with underlying medical problems, or anyone at all, including family members). Caring for others can now be done remotely, as noted above. Reckless also means not following the simple steps that can help to prevent the spread of the coronavirus: (1) washing hands regularly with soap for 20-30 s every couple hours, especially after having any contact with others; (2) being careful to wash hands after coming into contact with anything that comes into the home (cardboard boxes, mail, food products); (3) not touching the face until after hands have been thoroughly washed; (4) wearing a facemask when out in public, as is currently recommended; (5) keeping a safe physical distance from others (to avoid transmitting or receiving airborne droplets that may contain the coronavirus); (6) not physically congregating with several people at a time, including family members; and finally, and (7) staying physically healthy and resistant to infection.

\section{Pay Attention to Physical Health}

Here are some recommendations that may help maintain or improve physical health when cooped up at home. 
Exercise. Exercise at a moderate intensity for 30-45 min at home every day. The type of exercise needed must increase the heart rate and cause mild shortness of breath (called aerobic exercise). If necessary, purchase a stationary bicycle. A Drive Medical Folding Exercise Peddler can be purchased for as little as \$38 online. Moderate intensity exercise is known to improve immune function and potentially reduce risk and severity of respiratory viral infection (Martin et al. 2009), similar to the infection that the coronavirus causes. Exercise seven days per week at the same time each day to make it a habit, and spend time briefly outdoors each day to get sun and fresh air. Any change in physical activity, however, should be approved by a physician and gradually increased in duration and intensity to reach desired goals.

Sleep. Try to obtain 7 to $8 \mathrm{~h}$ of sleep per night, given research that indicates that not getting adequate sleep can adversely affect immunity and increase vulnerability to viral infections like the coronavirus (Opp and Krueger 2015; Ibarra-Coronado et al. 2015). Sleep during the daytime, however, may disrupt nighttime sleep. Go to bed at the same time every night and get up at the same time every morning. This will help to regulate your circadian rhythm.

Control Weight. Being at home all day long increases the risk of gaining weight, as boredom tends to promote snacking (and those snacks tend not to be carrots or celery). During this time, it is important to control weight by eating a healthy lowcalorie, high-protein, high-fiber diet (i.e., vegetables, fruits, high-protein foods, including fish). An example of a good diet to keep resilience up and weight down is the Mediterranean Diet, now rated \#1 by experts throughout the world (U.S. World \& News Report 2020).

Vitamin D. More than three-quarters of Americans have vitamin D levels below the 30-100 ng/mL recommended (Ginde et al. 2009). Vitamin D deficiency adversely affects immune functioning (Prietl et al. 2013), and a strong immune system is the only thing that stands between a person and infection by the coronavirus. The recommended dose of vitamin D supplementation is 2000 IU per day or more depending on blood level. For those with a history of kidney stones, however, excess vitamin D intake should be avoided (Malihi et al. 2016).

Other Nutraceuticals. Foods that contain nutrients that may help to boost immune function include Shiitake mushrooms (Dai et al. 2015; Feeney et al. 2014), Reishi mushrooms (Sanodiya et al. 2009), aged garlic (Percival 2016), and echinacea (Block and Mead 2003; Karsch-Volk et al. 2014). Besides vitamin D (the most important of all nutraceuticals for immune function), other vitamins that strengthen immunity include vitamin C and vitamin E (De la Fuente et al. 1998; Moriguchi and Muraga 2000). Zinc (Barnett et al. 2016) (80 mg/day during period of infection) and probiotics (Sharma et al. 2014) have also been shown to benefit the immune system.

Hydration. To remain resistant to the coronavirus and the consequences of coronavirus infection, it is essential to stay well hydrated. Staying well hydrated reduces risk of viral infection and the consequences of infection (which may often involve fever, diarrhea, nausea, etc.) (Cardemil et al. 2017). Well hydrated means drinking a minimum of 32-64 oz twice daily. Most fluids should be consumed in morning shortly after rising and again around noontime prior to lunch. Doing so will also increase urinary output requiring several trips to the restroom, thus increasing physical activity which helps to avoid deconditioning as well (for those who cannot or 
will not exercise). Fluid intake after about 3:00 in the afternoon should be minimal, and no fluids should be consumed after 6:00 PM. Drinking fluids in the late afternoon or evening will otherwise disrupt sleep at night, and as noted above, sleep is essential.

Highly recommended by experts (personal communication) is a concoction made by combining water $(80 \%)$ plus lemon juice $(20 \%)$, ingesting 1 quart before breakfast and 1 quart before lunch. This brew should be consumed using a straw to avoid contacting the acidic lemon juice to teeth enamel, which the former can eat away. Swishing one's mouth with baking soda after consumption is also a good idea to neutralize any remaining acidic lemon juice in the mouth. Adding to each quart an Airborne $($ ) tablet with $1000 \mathrm{mg}$ of vitamin $\mathrm{C}$ and other nutrients may provide extra protection.

Medications. Be careful to take medications as prescribed, ensure that an adequate supply of medications is available (since it may not be possible to get prescriptions renewed at the last minute, given supply shortages), and maintain regular contact with a physician (by telemedicine conference if necessary). Ensuring that medical conditions are well controlled will reduce vulnerability to both infection by the virus and the complications that may result from infection should that occur.

Spiritual Health. As noted above, spiritual health is closely related to both mental and physical health, and resistance to infection. Stay spiritually healthy, develop and nurture a close relationship with God, and volunteer to help family, friends, co-workers, and anyone else in need (but do it remotely whenever possible without physical contact). This will enhance physical health and resistance to infection, while spreading God's love to others.

\section{Religious Involvement and Immune Function}

Many systematic scientific studies have now reported a positive association between religious involvement and indicators of healthy immune function. These studies are often conducted in individuals with compromised immune systems, such as older adults (Koenig et al. 1997; Koenig and Cohen 2002; Lutgendorf et al. 2004; Kurita et al. 2011) and those with HIV/AIDS, other infections, or immune system disorders (see below). This research shows that religious involvement is associated with a reduction in pro-inflammatory cytokine levels and an increase in immune functions necessary to resist infection.

Likewise, research shows that those with compromised immune systems due to viral infections or cancer experience better immune function if they engage in religious activity (Woods et al. 1999; Sephton et al. 2001). More directly, research in both healthy and vulnerable populations (e.g., those with HIV/AIDS, hepatitis, sexually transmitted diseases) have found that religious activity is associated with decreased rates of infection (Merchant et al. 2003; Kagimu et al. 2012; Chen and VanderWeele 2018; Watson et al. 2019; Krause 2019); decreased viral load (concentration of viruses in blood) among those already infected (Ironson et al. 2006, 2011, 2017; Van Wagoner et al. 2016); and better outcomes from viral infection over 
time (hepatitis C infection; Raghavan et al. 2013). Furthermore, at least one randomized controlled trial has shown improved immune functions among those with viral infection in response to spiritual interventions (McCain et al. 2008). Oman and Riley (2018) provide a recent summary of studies examining the impact of religious or spiritual involvement on immune competence, infection risk behavior, rates of infection, adherence to treatments for infections, and programs for prevention or treatment of infection.

\section{Conclusion}

These are challenging times for all, especially for older adults and those with underlying medical conditions who are at increased risk of serious health problems from contracting the coronavirus and developing COVID-19 lung infection with potentially devastating consequences. Following the six suggestions above is one way to stay healthy and develop resistance for those who are religious. In the event of infection with the coronavirus, even then, the course of the illness will likely be less severe and recovery sooner due to increased emotional, social, physical, and spiritual resilience.

\section{Compliance with Ethical Standards}

Conflict of interest The author has no conflicts of interest.

\section{References}

Barnett, J. B., Dao, M. C., Hamer, D. H., Kandel, R., Brandeis, G., Wu, D., et al. (2016). Effect of zinc supplementation on serum zinc concentration and $\mathrm{T}$ cell proliferation in nursing home elderly: A randomized, double-blind, placebo-controlled trial. The American Journal of Clinical Nutrition, 103(3), 942-951.

Blanton, P. G. (2011). The other mindful practice: Centering prayer \& psychotherapy. Pastoral Psychology, 60(1), 133-147.

Block, K. I., \& Mead, M. N. (2003). Immune system effects of echinacea, ginseng, and astragalus: A review. Integrative cancer therapies, 2(3), 247-267.

Bonura, K. B. (2011). The psychological benefits of yoga practice for older adults: Evidence and guidelines. International Journal of Yoga Therapy, 21(1), 129-142.

Brown, R. L., Shahane, A. D., Chen, M. A., \& Fagundes, C. P. (2020). Cognitive reappraisal and nasal cytokine production following experimental rhinovirus infection. Brain, Behavior, \& ImmunityHealth, 1, 100012.

Cardemil, C. V., Parashar, U. D., \& Hall, A. J. (2017). Norovirus infection in older adults: Epidemiology, risk factors, and opportunities for prevention and control. Infectious Disease Clinics, 31(4), 839-870.

Chen, Y., \& VanderWeele, T. J. (2018). Associations of religious upbringing with subsequent health and well-being from adolescence to young adulthood: An outcome-wide analysis. American Journal of Epidemiology, 187(11), 2355-2364.

Coughlin, S. S. (2012). Anxiety and depression: Linkages with viral diseases. Public Health Reviews, $34(2), 7$ 
Dai, X., Stanilka, J. M., Rowe, C. A., Esteves, E. A., Nieves, C., Jr., Spaiser, S. J., et al. (2015). Consuming Lentinula edodes (Shiitake) mushrooms daily improves human immunity: A randomized dietary intervention in healthy young adults. Journal of the American College of Nutrition, 34(6), 478-487.

De la Fuente, M., Ferrandez, M. D., Burgos, M. S., Soler, A., Prieto, A., \& Miquel, J. (1998). Immune function in aged women is improved by ingestion of vitamins $\mathrm{C}$ and E. Canadian Journal of Physiology and Pharmacology, 76(4), 373-380.

Feeney, M. J., Dwyer, J., Hasler-Lewis, C. M., Milner, J. A., Noakes, M., Rowe, S., et al. (1136S). Mushrooms and health summit proceedings. The Journal of Nutrition, 144(7), 1128S-1136S.

Ford, K., \& Garzon, F. (2017). Research note: A randomized investigation of evangelical Christian accommodative mindfulness. Spirituality in Clinical Practice, 4(2), 92.

Ginde, A. A., Liu, M. C., \& Camargo, C. A. (2009). Demographic differences and trends of vitamin D insufficiency in the US population, 1988-2004. Archives of Internal Medicine, 169(6), 626-632.

Glaser, R., \& Kiecolt-Glaser, J. K. (2005). Stress-induced immune dysfunction: Implications for health. Nature Reviews Immunology, 5(3), 243-251.

Hazlett-Stevens, H., Singer, J., \& Chong, A. (2019). Mindfulness-based stress reduction and mindfulnessbased cognitive therapy with older adults: A qualitative review of randomized controlled outcome research. Clinical Gerontologist, 42(4), 347-358.

Ibarra-Coronado, E. G., Pantaleón-Martínez, A. M., Velazquéz-Moctezuma, J., Prospéro-García, O., Méndez-Díaz, M., Pérez-Tapia, M., et al. (2015). The bidirectional relationship between sleep and immunity against infections. Journal of Immunology Research. https://doi.org/10.1155/2015/67816 4.

Ironson, G., Henry, S. M., \& Gonzalez, B. D. (2017). Impact of stressful death or divorce in people with HIV: A prospective examination and the buffering effects of religious coping and social support. Journal of Health Psychology, 25, 606-616.

Ironson, G., Stuetzle, R., \& Fletcher, M. A. (2006). An increase in religiousness/spirituality occurs after HIV diagnosis and predicts slower disease progression over 4 years in people with HIV. Journal of General Internal Medicine, 21(Suppl 5), S62-68.

Ironson, G., Stuetzle, R., Ironson, D., Balbin, E., Kremer, H., George, A., et al. (2011). View of God as benevolent and forgiving or punishing and judgmental predicts HIV disease progression. Journal of Behavioral Medicine, 34(6), 414-425.

Kagimu, M., Guwatudde, D., Rwabukwali, C., Kaye, S., Walakira, Y., \& Ainomugisha, D. (2012). Religiosity for HIV prevention in Uganda: A case study among Christian youth in Wakiso district. African Health Sciences, 12(1), 17-25.

Karsch-Völk, M., Barrett, B., Kiefer, D., Bauer, R., Ardjomand-Woelkart, K., \& Linde, K. (2014). Echinacea for preventing and treating the common cold. Cochrane Database of Systematic Reviews, 20(2), CD000530.

Koenig, H. G., Al-Zaben, F., \& VanderWeele, T. J. (2020). Religion and psychiatry: Recent developments in research. British Journal of Psychiatry Advances. https://doi.org/10.1192/bja.2019.81.

Koenig, H. G., \& Cohen, H. J. (2002). The link between religion and health: Psychoneuroimmunology and the faith factor. New York, NY: Oxford University Press.

Koenig, H. G., Cohen, H. J., George, L. K., Hays, J. C., Larson, D. B., \& Blazer, D. G. (1997). Attendance at religious services, interleukin-6, and other biological indicators of immune function in older adults. International Journal of Psychiatry in Medicine, 27, 233-250.

Koenig, H. G., King, D. E., \& Carson, V. B. (2012). Handbook of religion and health (2nd ed.). New York, NY: Oxford University Press.

Krause, N. (2019). Religion and health among Hispanics: Exploring variations by age. Journal of Religion and Health, 58(5), 1817-1832.

Kurita, A., Takase, B., Shinagawa, N., Kodani, E., Okada, K., Iwahara, S., et al. (2011). Spiritual activation in very elderly individuals assessed as heart rate variability and plasma IL/10/IL-6 ratios. International Heart Journal, 52(5), 299-303.

Lutgendorf, S. K., Russell, D., Ullrich, P., Harris, T. B., \& Wallace, R. (2004). Religious participation, interleukin-6, and mortality in older adults. Health Psychology, 23(5), 465-475.

Malihi, Z., Wu, Z., Stewart, A. W., Lawes, C. M., \& Scragg, R. (2016). Hypercalcemia, hypercalciuria, and kidney stones in long-term studies of vitamin D supplementation: A systematic review and meta-analysis. American Journal of Clinical Nutrition, 104(4), 1039-1051.

Martin, S. A., Pence, B. D., \& Woods, J. A. (2009). Exercise and respiratory tract viral infections. Exercise and Sport Sciences Reviews, 37(4), 157. 
McCain, N. L., Gray, D. P., Elswick, R. K., Robins, J. W., Tuck, I., Walter, J. M., et al. (2008). A randomized clinical trial of alternative stress management interventions in persons with HIV infection. Journal of Consulting \& Clinical Psychology, 76(3), 431-441.

Merchant, A. T., Pitiphat, W., Ahmed, B., Kawachi, I., \& Joshipura, K. (2003). A prospective study of social support, anger expression and risk of periodontitis in men. Journal of the American Dental Association, 134(12), 1591-1596.

Moriguchi, S., \& Muraga, M. (2000). Vitamin E and immunity. Vitamins and Hormones, 59(2000), 305-336.

Numbers, R. L., \& Amundsen, D. W. (1986). Caring and curing: Health and medicine in the Western Religious Traditions. Baltimore: John Hopkins University Press.

Oman, D., \& Riley, L. W. (2018). Infectious diseases, religion, and spirituality. In D. Oman (Ed.), Why religion and spirituality matter for public health (pp. 153-163). Cham: Springer.

Opp, M. R., \& Krueger, J. M. (2015). Sleep and immunity: a growing field with clinical impact. Brain, Behavior, and Immunity, 47, 1-3.

Pandya, S. P. (2019). Meditation program mitigates loneliness and promotes wellbeing, life satisfaction and contentment among retired older adults: A two-year follow-up study in four South Asian cities. Aging \& Mental Health, 22, 1-13.

Percival, S. S. (2016). Aged garlic extract modifies human immunity. The Journal of nutrition, 146(2), 433S-436S.

Pressman, S. D., \& Black, L. L. (2012). Positive emotions and immunity. In S. C. Segerstrom \& S. Segerstrom (Eds.), The Oxford handbook of psychoneuroimmunology (pp. 92-104). Oxford: Oxford University Press.

Prietl, B., Treiber, G., Pieber, T. R., \& Amrein, K. (2013). Vitamin D and immune function. Nutrients, 5(7), 2502-2521.

Raghavan, R., Ferlic-Stark, L., Clarke, C., Rungta, M., \& Goodgame, R. (2013). The role of patient religiosity in the evaluation and treatment outcomes from chronic HCV infection. Journal of Religion and Health, 52, 79-90.

Sanodiya, B. S., Thakur, G. S., Baghel, R. K., Prasad, G. B. K. S., \& Bisen, P. S. (2009). Ganoderma lucidum: A potent pharmacological macrofungus. Current Pharmaceutical Biotechnology, 10(8), 717-742.

Sephton, S. E., Koopman, C., Schaal, M., Thoresen, C., \& Spiegel, D. (2001). Spiritual expression and immune status in women with metastatic breast cancer: An exploratory study. Breast Journal, 7(5), 345-353.

Sharma, R., Kapila, R., Kapasiya, M., Saliganti, V., Dass, G., \& Kapila, S. (2014). Dietary supplementation of milk fermented with probiotic Lactobacillus fermentum enhances systemic immune response and antioxidant capacity in aging mice. Nutrition Research, 34(11), 968-981.

U.S. News \& World Report (2020). Best diets overall. Retrieved January 5, 2020, from https://healt h.usnews.com/best-diet/best-diets-overall (for methodology, see https://health.usnews.com/best-diet/ experts).

Van Wagoner, N., Elopre, L., Westfall, A. O., Mugavero, M. J., Turan, J., \& Hook, E. W. (2016). Reported church attendance at the time of entry into HIV care is associated with viral load suppression at 12 months. AIDS and Behavior, 20(8), 1706-1712.

Watson, R. J., Allen, A., Pollitt, A. M., \& Eaton, L. A. (2019). Risk and protective factors for sexual health outcomes among Black bisexual men in the US: Internalized heterosexism, sexual orientation disclosure, and religiosity. Archives of Sexual Behavior, 48(1), 243-253.

Wilson, T. E., Weedon, J., Cohen, M. H., Golub, E. T., Milam, J., Young, M. A., et al. (2017). Positive affect and its association with viral control among women with HIV infection. Health Psychology, $36(1), 91$.

Woods, T. E., Antoni, M. H., Ironson, G. H., \& Kling, D. W. (1999). Religiosity is associated with affective and immune status in symptomatic HIV-infected gay men. Journal of Psychosomatic Research, 46(2), 165-176.

Publisher's Note Springer Nature remains neutral with regard to jurisdictional claims in published maps and institutional affiliations. 